\title{
The Synthesis and Anti-Bacterial Activities of $N$-carboxymethyl Rhodanines
}

\author{
Ming-Xia Song ${ }^{1}$, Chang-Ji Zheng ${ }^{2}$, Xian-Qing Deng ${ }^{1}$, Zhi-Yu Wei ${ }^{2}$ and Hu-Ri Piao ${ }^{2 *}$ \\ ${ }^{1}$ Jing Gangshan University College of Medicine, Ji'an 343100, P R China \\ ${ }^{2}$ Key Laboratory of Natural Resources and Functional Molecules of the Changbai Mountain, Affiliated Ministry of Education; Yanbian University College of Pharmacy, \\ Yanji 133002, P R China
}

\begin{abstract}
A large number of reports have been published in recent years regarding the use of $N$-carboxymethyl rhodanines as antimicrobial agents. Molecules belonging to this structural class have been reported to exhibit good inhibitory activities towards various Gram-positive bacteria, including several multidrug-resistant strains such as methicillinresistant Staphylococcus aureus and quinolone-resistant Staphylococcus aureus. In this mini-review, we have provided a summary of recent research directed towards the synthesis of $N$-carboxymethyl rhodanines, and their pharmacological evaluation as antimicrobial agents.
\end{abstract}

Keywords: Synthesis; Antibacterial activity; Methicillin-resistant Staphylococcus aureus; Quinolone-resistant Staphylococcus aureus; $\mathrm{N}$-carboxymethyl rhodanine; Chalcone

\section{Introduction}

The treatment of bacterial infections currently represents a significant therapeutic challenge throughout the world. Although antibiotics are still available for most common infections, the emergence of new infectious diseases-as well as increasing levels of resistance in some pathogens-threaten to undermine the effectiveness of the few remaining drugs available for the treatment of these infections $[1,2]$. The lack of innovation in the development of new antibiotics has greatly increased the challenge of treating and eradicating certain infecting pathogens, which lead to a $60 \%$ fall in the numbers of new approvals and few novel molecules [2]. While this trend is changing, there is an urgent need for the development of new antibacterial agents with divergent and unique structural features that operate via a different mechanisms of action to those of existing antimicrobial agents [2,3].

Heterocyclic compounds have been used extensively in the field of medicinal chemistry, where they occupy a central position in the development of new and novel therapeutic agents. Rhodanines are fivemembered heterocyclic compounds, which have a sulfur atom at their 1-position, a thiocarbonyl group at their 2-position, a nitrogen atom at their 3-position, and a carbonyl group at their 4-position. These compounds belong to an interesting class of heterocyclic molecules, which have attracted considerable attention from chemists over the last 20 years because of their wide range of biological properties, including their antibacterial [4-9], antifungal [10-13], antidiabetic [14-16], antiinflammatory [17-18], antituberculosis [19], anticancer [20,21], antiHIV [22,23], antiparasitic [24], hypnotic [25], and anthelmintic [26,27] activities.

Although several reviews have been published concerning the chemistry and biological activities of rhodanines [28,29], there have been no reviews in the literature pertaining to the anti-bacterial properties of $\mathrm{N}$-carboxymethyl rhodanines. In the current review, we provide a summary of recent research progress towards the synthesis of $N$-carboxymethyl rhodanines, with particular emphasis on the antibacterial activities of these compounds.

\section{Preparation of $\mathrm{N}$-Carboxymethyl Rhodanines}

Several methods have been reported in the literature for the synthesis of rhodanines, and these methods are also applicable to the synthesis of $\mathrm{N}$-carboxymethyl rhodanines. There are several different strategies available for the synthesis of $\mathrm{N}$-substituted rhodanines, which generally involve the use of three specific components, including a substitutedamine, carbon disulfide and chloroacetic acid. N-Substituted rhodanines have traditionally been synthesized according to a onepot three-component condensation reaction (Scheme 1) [30-32]. This particular reaction begins with the nucleophilic attack of the carbon of carbon disulfide by the amine to give a thioamide. The resulting sulfur nucleophile then reacts with chloro- or bromo-acetic acid, followed by intramolecular cyclization with loss of water to give the desired rhodanine. It is important to note, however, that the amenability of this method to high throughput synthesis has been limited by its requirement for harsh reaction conditions and extended reaction times.

To address some of the issues associated with this reaction, Nitsche and Klein [32] reported the development of an improved one-pot process for the synthesis of $\mathrm{N}$-arylrhodanines by the reaction of bis(carboxymethyl)trithiocarbonate with anilines in water under microwave irradiation (Scheme 2). This particular method allowed for alkyl- and benzyl-amines to be converted to the corresponding rhodanines in an atom-efficient manner according to a one-pot, threestep protocol based on carbon disulfide and chloroacetic acid in short reaction times and good to excellent yields.

Alizadeh et al. [33] reported the development of a simple and effective one-pot procedure for the synthesis of rhodanine derivatives using commercially available starting materials with water as a solvent (Scheme 3). The authors of this particular study also provided experimental evidence in support of their proposed reaction mechanism for the reaction of the amine with carbon disulfide in the presence of DAAD. As shown in Scheme 4, the proposed mechanism suggested that the initial addition of the amine to carbon disulfide would result in the formation of the reactive alkylammonium carbodithioate 4 , which would react with the acetylenic ester 2 to yield intermediate 5 .

*Corresponding author: Hu-Ri Piao, Yanbian University College of Pharmacy, Yanji, Jilin 133002, P R China, Tel: + 86-433-2435003; Fax: + 86-433-2435026; E-mail: piaohuri@aliyun.com

Received April 21, 2014; Accepted May 21, 2014; Published May 23, 2014

Citation: Song MX, Zheng CJ, Deng XQ, Wei ZY, Piao HR (2014) The Synthesis and Anti-Bacterial Activities of $\mathrm{N}$-carboxymethyl Rhodanines. Med chem 4: 441 448. doi:10.4172/2161-0444.1000177

Copyright: $\odot 2014$ Song MX, et al. This is an open-access article distributed under the terms of the Creative Commons Attribution License, which permits unrestricted use, distribution, and reproduction in any medium, provided the original author and source are credited. 


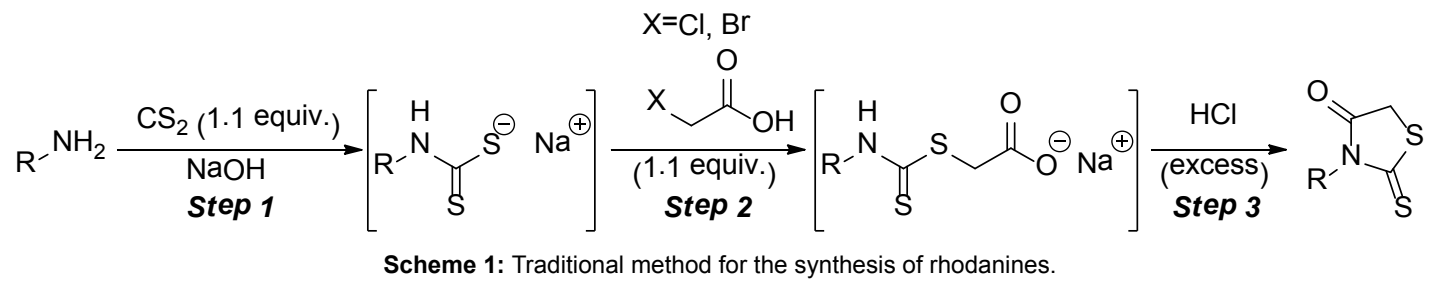

$$
\underset{\mathrm{RNH}_{2}}{\stackrel{\text { 1.) } \mathrm{CS}_{2}, \mathrm{NaOH}, \mathrm{MW}}{\text { 2.) } \mathrm{ClCH}_{2} \mathrm{CO}_{2} \mathrm{H}, \mathrm{MW}}}
$$

Scheme 2: Klein's improved synthesis of rhodanines.

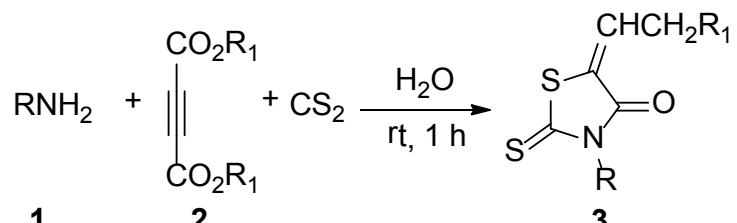

Scheme 3: Hosseinpour's synthesis of rhodanines.

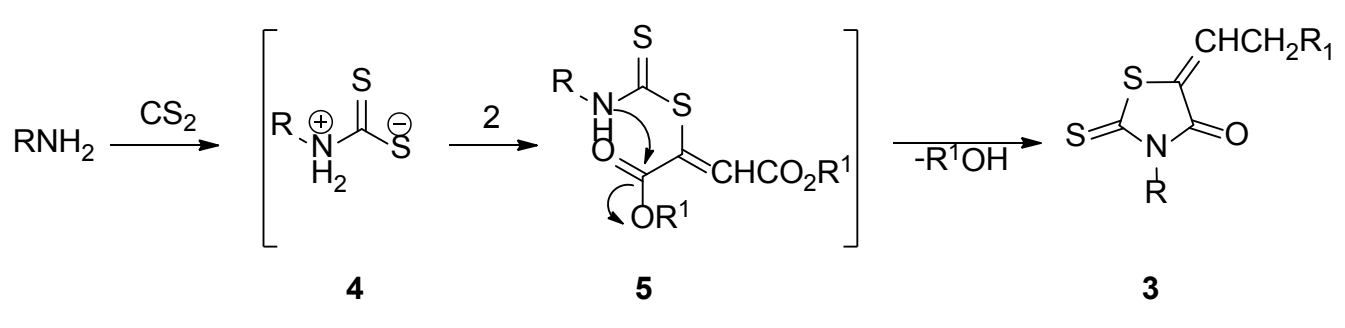

Scheme 4: Possible mechanism for the formation of rhodanines.<smiles>[R]N1C(=O)C(=C([SiH3])[AsH3])SC1=S</smiles>

5



$8 \mathrm{~h}, \mathrm{r}$. t.

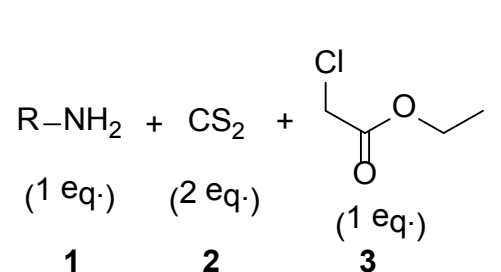

3

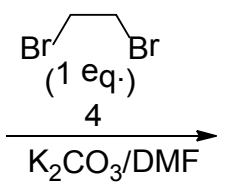

$8 \mathrm{~h}, \mathrm{r} . \mathrm{t}$.<smiles>[R]N1C(=O)C(=C2SCCS2)SC1=S</smiles>

5

Scheme 5: Chauhan's synthesis of rhodanines.

Subsequent cyclization of 5 would occur with the loss of $\mathrm{R}^{1} \mathrm{OH}$ to give compound 3 [34].

Singh and Chauhan [35] reported a novel multi-component process for the synthesis of ketene dithioacetal rhodanines involving the reaction of a primary amine with carbon disulfide, ethyl chloroacetate, and an alkyl halide in DMF (Scheme 5). The authors of this study also investigated the effects of different bases on the performance of the reaction and found that potassium carbonate provided the best results of all of the bases tested, affording moderate to good yields of the desired products at room temperature [35].

\section{Antibacterial Activity of $\mathrm{N}$-Carboxymethyl Rhodanines}

The anti-microbial activity of rhodanines has been known for over 50 years, and numerous studies have been reported involving the design and synthesis of anti-bacterial agents based on this heterocycle [36-39]. Furthermore, there has been a recent increase in the number of reports concerning the anti-bacterial activities of $\mathrm{N}$-carboxymethyl rhodanines (Figure 1). Herein, we have provided a summary of recent reports pertaining to the anti-bacterial activities of $\mathrm{N}$-carboxymethyl rhodanines.

Methicillin-resistant Staphylococcus aureus (MRSA) has become 


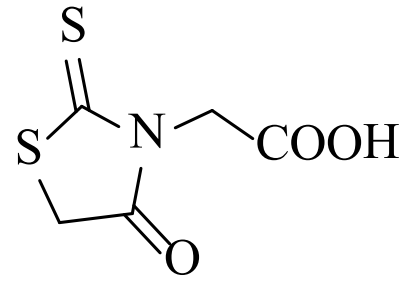

Figure 1: The structure of $\mathrm{N}$-carboxymethyl rhodanine.

a major threat to human health throughout the world. It has been estimated that more than $50 \%$ of all staphylococcus infections are caused by MRSA. Furthermore, most strains of MRSA are resistant to $\beta$-lactam and macrolide/azalide antibiotics. Although some MRSA infections can be treated, the resistance rates are increasing, and there is therefore an urgent need to develop new therapeutic agents against MRSA with high levels of potency. Hardej et al. [40] reported the synthesis of a series of $N$-carboxymethyl-5-arylmethylidenerhodanines, which were screened for their activity against MRSA (Figure 2) [40]. Two of these compounds (1a and 1b) exhibited higher levels of activity towards MRSA (MICs of 1.95 and $3.9 \mu \mathrm{g} / \mathrm{mL}$ ) than the reference antibiotic ciprofloxacin (MIC $7.8 \mu \mathrm{g} / \mathrm{mL}$ ). Furthermore, the activities of these compounds towards MRSA were not affected by the absence or presence of $10 \%$ FBS.

Patel et al. [41] synthesized a series of C5-analogues of compound $1 \mathrm{~b}$ in attempt to identify the optimal C5-arylidene substituent. All of the rhodanine analogues synthesized in this study were tested for their in vitro activity against a panel of MRSA strains, including MRSA ATCC 34404, MRSA ATCC 700787, MRSA ATCC 700698, MRSA ATCC BAA-39, MRSA CA ATCC BAA-1680 and MRSA ST239 HS770. The SAR data for these compounds clearly emphasized the importance of a hydrophobic aromatic substituent on the benzylidene moiety. Three compounds $(2 \mathrm{a}-\mathrm{c})$ exhibited improved efficacy over $1 \mathrm{~b}$ against MRSA ATCC 34404 with an MIC value of $0.98 \mu \mathrm{g} / \mathrm{mL}$ (Figure 3).

Peptidoglycan is an essential cell-wall polymer unique to prokaryotic cells that provides the rigidity, flexibility and strength required for bacterial cells to grow and divide, whilst withstanding the high internal osmotic pressure. Several Mur enzymes (MurC-F) were discovered to be involved in the early intracellular stages of cytoplasmic peptidoglycan precursor biosynthesis. For this reason, the bacterial Mur ligases became new targets for anti-bacterial drug discovery. Tomasić et al. [42] prepared a series of hydroxy-substituted 5-benzylidenethiazolidin-4-ones as Mur ligase inhibitors. The $\mathrm{IC}_{50}$ values of the representative inhibitor 3 towards MurE and MurF were 19 and $6 \mu \mathrm{M}$, respectively. Unfortunately, however, compound 3 was found to be a weak inhibitor of bacterial growth in vitro with an MIC value of $128 \mu \mathrm{g} / \mathrm{mL}$ against two strains of Gram-positive bacteria (i.e., S. aureus ATCC 29213 and Enterococcus faecalis ATCC 29212). Furthermore, compound 3 exhibited an MIC value of $>128 \mu \mathrm{g} / \mathrm{mL}$ towards two strains of Gram-negative bacteria (i.e., E. coli ATCC 25922 and Pseudomonas aeruginosa ATCC 27853). Compound 4, which was prepared to provide improved $\log \mathrm{P}$ properties over compound 3 , gave the same results with MIC values $>128 \mu \mathrm{g} / \mathrm{mL}$ against all of the bacterial strains tested in the study (Figure 4) [43].

Alegaon and Alagawadi [44] reported the synthesis of hybrid molecules of imidazo[1,3,4]thiadiazoles and $N$-carboxymethyl rhodanine and the subsequent evaluation of their antibacterial activities. Compound 5 is representative of this series and showed significant activity against $S$. aureus (MIC $=4 \mu \mathrm{g} / \mathrm{mL}$ ), as well as moderate activity against E. coli $(\mathrm{MIC}=32 \mu \mathrm{g} / \mathrm{mL}$ ) (Figure 5). Furthermore, compound

5 showed good antifungal activity against several strains of fungi, including Candida albicans (ATCC 2091), Aspergillus flavus (NCIM No. 524), Aspergillus niger (ATCC 6275), and Cryptococcus neoformans (clinical isolate).

Based on the potential antibacterial activities of $\mathrm{N}$-carboxymethyl rhodanines and their amenability to structural modification, our group started a new project aimed at designing novel antibacterial agents with an $N$-carboxymethyl rhodanine nucleus. In 2009, we synthesized a series of hybrid compounds containing chalcone and $N$-carboxymethyl rhodanine moieties (6a-s) with the aim of harnessing the antibacterial activities of both chalcones and $N$-carboxymethyl rhodanines (Figure 6) [45]. In this particular study, the target compounds were prepared in good yields by the Knoevenagel condensation of a range of (E)-4-(3-substitutedphenyl-3-oxoprop-1-enyl)benzaldehydes with $\mathrm{N}$-carboxymethyl rhodanine. Subsequent pharmacologic evaluation revealed that some of these compounds possessed significant antibacterial activities towards a range of Gram-positive bacteria, including S. aureus RN 4220, S. aureus KCTC 503, S. aureus KCTC 209, S. mutans KCTC 3065 and S. mutans KCTC 3289. Furthermore, derivative $6 \mathrm{k}$, which had an MIC value of $2 \mu \mathrm{g} / \mathrm{mL}$ against all of these<smiles>O=C(O)C(Cc1ccccc1)N1C(=O)S/C(=C\c2ccc(Cl)c(Cl)c2)C1=O</smiles>
$1 \mathrm{a}$

Figure 2: The structures of compounds $1 \mathrm{a}$ and $1 \mathrm{~b}$<smiles>O=C(O)C(Cc1ccccc1)N1C(=O)/C(=C/c2cccc(-c3ccccc3)c2)NC1=S</smiles>

Figure 3: The structures of compounds $2 \mathrm{a}, 2 \mathrm{~b}$ and $2 \mathrm{c}$.<smiles>O=C(O)CN1C(=O)/C(=C/c2cc(O)c(O)cc2O)SC1=S</smiles><smiles>COc1cc(/C=C2\SC(=S)N(CC(=O)O)C2=O)cc(OC)c1OC</smiles>

Figure 4: The structures of compounds 3 and 4 .<smiles>COc1cc(-c2nn3c(/C=C4\SC(=S)N(CC(=O)O)C4=O)c(-c4ccc(Br)cc4)nc3s2)cc(OC)c1OC</smiles>

Figure 5: The structure of compound 5 . 
<smiles>O=C(O)CN1C(=O)/C(=C/c2ccc(/C=C/C(=O)c3c#[R]ccc3)cc2)SC1=S</smiles>

Figure 6: The antibacterial activity of some compounds in series 6.

strains, was as active as the standard drug norfloxacin. However, none of these compounds exhibited inhibitory activity towards the growth of the Gram-negative bacteria E. coli CCARM 1924 and E. coli CCARM 1356 at $32 \mu \mathrm{g} / \mathrm{mL}$. Analysis of the SAR of this series of compounds revealed that those bearing electron-donating groups showed lower levels of activity than those bearing electron-withdrawing halogen substituents (e.g., $6 \mathrm{a}, 6 \mathrm{~d} v s 6 \mathrm{~g}, 6 \mathrm{j}$ ), and that para-substituted derivatives displayed better activity than the corresponding ortho-substituted compounds (6g, 6j vs 6f, 6h) (Figure 6).

Although some of the chalcone-based $N$-carboxymethyl rhodanines were found to possess promising antibacterial activities, very little is still known about these compounds in terms of identifying which parts of their structures are essential to their antibacterial activity, despite some limited SAR. With this in mind, Jin et al. [46] designed and synthesized a series of chalcone derivatives containing non-substituted rhodanine (7a-e) and evaluated their antimicrobial activities against several different strains of bacteria (Figure 7). Some of the compounds in this series were found to be inactive against the bacteria evaluated in this study at $64 \mu \mathrm{g} / \mathrm{mL}$. These data therefore supported the importance of the presence of the $\mathrm{N}$-carboxymethyl moiety in terms of delivering potent antibacterial activity.

Based on these results, Jin et al. [46] synthesized several chalcone analogues bearing an $\mathrm{N}$-carboxymethyl rhodanine $(9 \mathrm{a}-\mathrm{q})$ and tested their antibacterial activities against several different strains of bacteria (Figure 7). These particular compounds exhibited significant levels of antibacterial activity with MIC values in the range of $2-16 \mu \mathrm{g} / \mathrm{mL}$. Several other compounds, including compounds $8 \mathrm{a}-\mathrm{j}$ and $9 \mathrm{a}-\mathrm{q}$ were synthesized also exhibited significant levels of activity against MRSA CCARM 3167, MRSA CCARM 3506, QRSA CCARM 3505 and QRSA CCARM 3519, with MIC values in the range of $2-8 \mu \mathrm{g} / \mathrm{mL}$. These data demonstrated that the introduction of a hydrophobic side chains on the $\mathrm{N}$-carboxymethyl moiety of the rhodanine led to significant increases in the potency compared with the previously reported compounds (6as), especially against the multidrug-resistant clinical isolates.

To establish comprehensive SAR and obtain new and improved antibiotics, several groups continued to work towards the modification of chalcones bearing $\mathrm{N}$-carboxymethyl rhodanines, and two series of optical isomers (10a-i and 11a-i) were designed and synthesized to investigate the impact of the stereochemical configuration (i.e., $R$ - or $S$-) on the anti-bacterial activity of the compounds (Figure 8) [47]. The majority of these compounds showed good levels of inhibition with MIC values in the range of $1-16 \mu \mathrm{g} / \mathrm{mL}$ against $S$. aureus. In particular, compounds $10 \mathrm{~g}$ and $10 \mathrm{~h}(\mathrm{MIC}=1 \mu \mathrm{g} / \mathrm{mL})$ were two-fold more potent than the positive control norfloxacin (MIC $=2 \mu \mathrm{g} / \mathrm{mL}$ ) against $S$. aureus $\mathrm{RN}$ 4220. These compounds also exhibited good inhibitory activity against MRSA 3167 and 3506, with an MIC value of $1 \mu \mathrm{g} / \mathrm{mL}$. The results from this study effectively confirmed that the stereochemical configuration had no impact on the anti-bacterial activity of these compounds. In a separate study, several alternative $N$-carboxymethyl side chains were designed and attached to the chalcone bearing $\mathrm{N}$-carboxymethyl rhodanines to give compounds $12 \mathrm{a}-\mathrm{n}$ and $13 \mathrm{a}-\mathrm{n}$
(Figure 9). These compounds also displayed promising antimicrobial activities against several Gram-positive strains of bacteria and multidrug-resistant clinical isolates, including S. aureus RN 4220, S. aureus KCTC 209, S. aureus KCTC 503, MRSA CCARM 3167 and 3506, QRSA CCARM 3505 and 3519 [48].

At the same time, we also prepared a series of $(Z)-5-\{4-[2-(2-$ substitutedphenyl)-2-oxoethoxy] benzylidene\}-2-thioxothiazolidin4-ones $(14 \mathrm{a}-\mathrm{m})$ by changing the chalcone moiety to a 4-(2-oxo-2phenylethoxy)benzene in the compound $6 \mathrm{k}$ whilst simultaneously introducing different substituents to the terminal phenyl ring (Figure 10) [49]. This design aimed to reduce the rigidity of the chalcone moiety in $6 \mathrm{k}$ with the expectation that this would afford enhanced levels of binding to the receptor and greater activity. Furthermore, the acetic acid group at the 3-position of the rhodanine was removed completely or replaced with different aromatic amino acid side chains (including L-phenylalanine, L-tyrosine and L-tryptophan), which resulted in four different series of compounds (15a-m, 16a-m, 17a-m and $18 \mathrm{a}-\mathrm{m})$ (Figure 10).

All of the synthesized compounds were screened for their activity against three different strains of Gram-positive bacteria (i.e., S. aureus RN 4220, S. aureus KCTC 209 and S. aureus KCTC 503) and one strain of Gram-negative bacteria (i.e., Escherichia coli 1356). Most of the synthesized compounds showed potent inhibitory activity against the three strains of Gram-positive bacteria with MIC values in the range of $1-32 \mu \mathrm{g} / \mathrm{mL}$. Compound $18 \mathrm{c}$, bearing a $4-\mathrm{Cl}$ substituent on its terminal phenyl ring, exhibited the highest level of activity with an MIC value of $1 \mu \mathrm{g} / \mathrm{mL}$ against all three of the Gram-positive strains. The inhibitory activities of these compounds were also tested against several clinical isolates of multidrug-resistant Gram-positive bacteria, including MRSA CCARM 3167, MRSA CCARM 3506, QRSA CCARM 3505 and QRSA CCARM 3519, and compounds 16i, 18b and 18c were found to be the most potent, with MIC values of $1 \mu \mathrm{g} / \mathrm{mL}$ against all of these multidrug-resistant strains. SAR analysis of the compounds synthesized in this study also revealed several trends, including (I) the $N$-carboxymethyl moiety was necessary for anti-bacterial activity against Gram-positive bacteria; and (II) the inclusion of a phenmethyl moiety or other hydrophobic substituent at the $\mathrm{N}$-carboxymethyl moiety was necessary to increase the antibacterial activity.

In a subsequent study, we continued with our work towards the modification of $\mathrm{N}$-carboxymethyl rhodanines by introducing different groups at the 5-position of these compounds to give four different series of analogues, including 19a-x, 20a-t, 21a-p and 22a-x (Figure 11) [5053]. The antimicrobial activities of all of the compounds were evaluated against several different strains of bacteria, including multidrugresistant clinical isolates. In their respective series, compounds $19 \mathrm{k}$, $20 \mathrm{~g}, 21 \mathrm{c}$, and $22 \mathrm{l}$, bearing $4-\mathrm{Br}, 4-\mathrm{CH}_{3}, 4-\mathrm{Cl}$, and $2,5-\mathrm{Cl}_{2}$ substituents, respectively, exhibited the strongest antimicrobial activities with MIC values of $1,1,8$, and $2 \mu \mathrm{g} / \mathrm{mL}$ against MRSA CCARM 3167/3506 or QRSA CCARM 3505/3519, respectively.

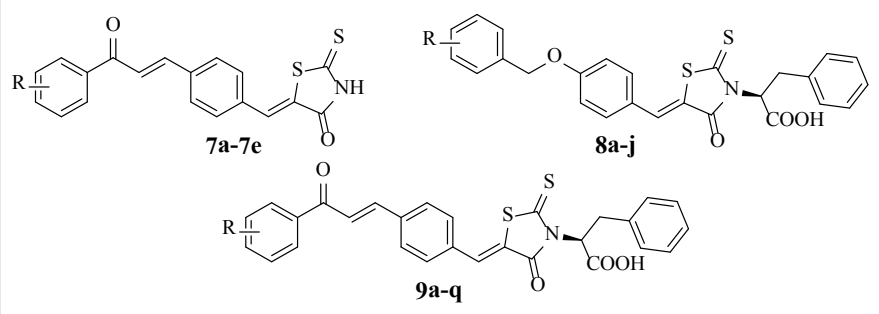

Figure 7: The structure of series 7,8 and 9 . 
<smiles>[R]N1C(=O)/C(=C/c2ccc(/C=C/C(=O)c3ccc4ccccc4c3)cc2)SC1=S</smiles>

10a-i<smiles>[R]N1C(=O)/C(=C/c2ccc(/C=C/C(=O)c3ccc(-c4ccccc4)cc3)cc2)SC1=S</smiles>

11a-i

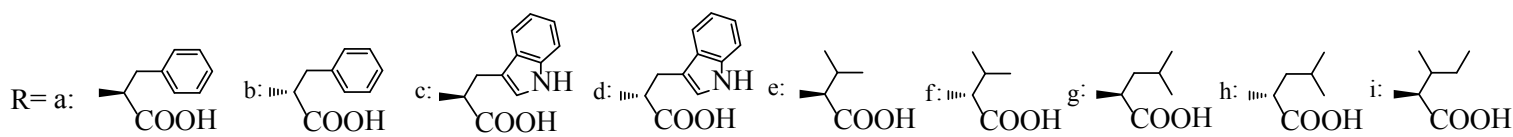

Figure 8: The structure of series of compounds 10a-l and 11a-i.<smiles>[R10]C=C1C(=O)N(C(C(=O)O)C(C)CC)C(=S)S1=Cc1ccc(C=CC(=O)c2cc[R1]cc2)cc1</smiles><smiles>O=C(/C=C/c1ccc(/C=C2\SC(=S)N([C@@H](Cc3c[nH]c4ccccc34)C(=O)O)C2=O)cc1)c1c[R1]ccc1</smiles>

Figure 9: The structure of series 12a-n and 13a-n.<smiles></smiles>

14a-m<smiles>COCC(=O)c1c[R1]ccc1</smiles><smiles>COc1ccc(/C=C2\SC(=S)NC2=O)cc1</smiles>
15a-m<smiles>[R]C=CC(=C[R])C(=O)COC</smiles>

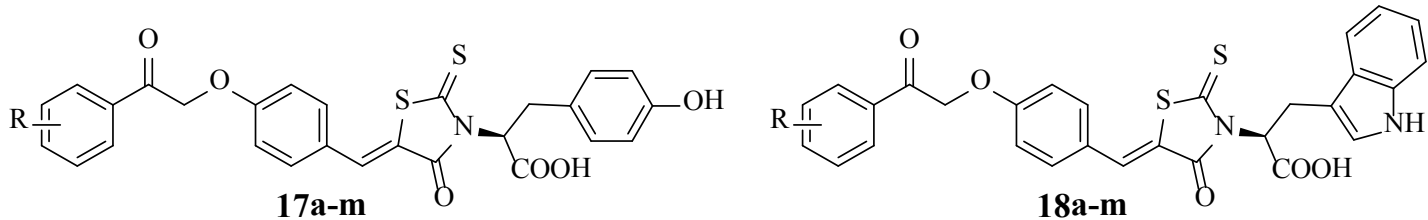

$\mathrm{R}=\mathrm{a}: 2-\mathrm{Cl} \quad$ b: $3-\mathrm{Cl} \quad$ c: $4-\mathrm{Cl} \quad$ d: $2,4-\left(\mathrm{Cl}_{2} \quad\right.$ e:2-Br $\quad$ f: $3-\mathrm{Br} \quad \mathrm{g}: 4-\mathrm{Br} \quad$ h: $2-\mathrm{F} \quad$ i: $4-\mathrm{F} \quad \mathrm{j}: \mathrm{H} \quad$ k: $4-\mathrm{CH}_{3} \quad$ 1: $3-\mathrm{OCH}_{3}$

Figure 10: The structure of series of 14a-m, 15a-m, 16a-m, 17a-m and 18a-m.<smiles>[R][R]1cccc(COc2ccc3cc(/C=C4\SC(=S)N(C(C)C(=O)O)C4=O)ccc3c2)c1</smiles><smiles>[Z10][R]=C1SC(=S)N([C@@H](Cc2ccccc2)C(=O)O)C1=O</smiles><smiles>[R]O[Z10]1cccc(COc2ccc3cc(/C=C4\SC(=S)N([C@H]([R])C(=O)O)C4=O)c(Cl)nc3c2)c1</smiles>

$\mathrm{R}^{\prime}=\mathrm{CH}_{2} \mathrm{C}_{6} \mathrm{H}_{5}$ $\mathrm{CH}\left(\mathrm{CH}_{3}\right) \mathrm{CH}_{2} \mathrm{CH}_{3}$ $\mathrm{CH}_{2} \mathrm{CH}\left(\mathrm{CH}_{3}\right)_{2}$

Figure 11: The structure of series of 19a-x, 20a-t, 21a-p and 22a-x.

Molecules containing a pyrazole ring are known to possess a wide variety of biological activities [54,55], and there has been a recent increase in studies directed towards the use of pyrazole derivatives as potential antimicrobial agents [56-60]. With this in mind, we designed and synthesized a new series of pyrazole-based $N$-carboxymethyl rhodanines $(23 \mathrm{a}-\mathrm{p})$ and evaluated their antimicrobial activity (Figure 12) [61]. Compounds 23f, 23i, and 23o showed the highest antimicrobial activities of these compounds with MIC values of $8 \mu \mathrm{g} / \mathrm{mL}$ against 


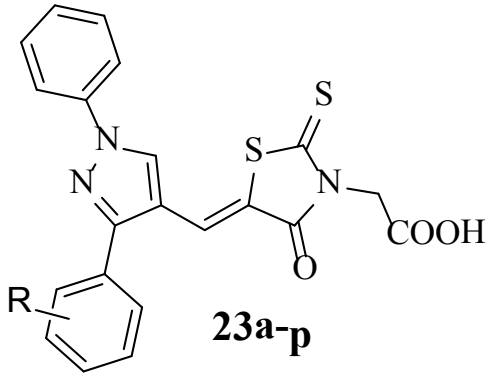

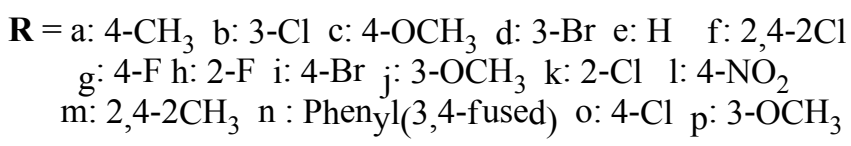<smiles>[R]c1cccc(-c2nn(-c3ccccc3)cc2/C=C2\SC(=S)N(C(Cc3ccccc3)C(=O)O)C2=O)c1</smiles>

$\mathbf{R}=\mathrm{a}: 4-\mathrm{Cl}$ b: $2,4-2 \mathrm{Cl}$ c: $2,4-2 \mathrm{CH}_{3}$ d: $4-\mathrm{CH}_{3}$ e: $\mathrm{H}$ f: $3-\mathrm{Br}$ g: 4-F h: 4-Br i: Phen $\mathrm{yl}(3,4-$ fused $) \mathrm{j}: 4-\mathrm{NO}_{2}$ k: $2-\mathrm{OCH}_{3}$ 1: $4-\mathrm{OCH}_{3}$ m: $2-\mathrm{Cl}$ n: $3-\mathrm{OCH}_{3}$ o: $2-\mathrm{F}$

Figure 12: The structure of series of 23a-p and 24a-o.<smiles>[R]c1cccc(Oc2c(/C=C3\SC(=S)N([C@H]([R])C(=O)O)C3=O)c(C)nn2-c2ccccc2)c1</smiles>

$\mathrm{R}^{\prime}=$ 25:<smiles>CCc1ccccc1</smiles>
26:<smiles>CCc1ccc(O)cc1</smiles>
27:<smiles>CCc1c[nH]c2ccccc12</smiles>
28:<smiles>CC(C)C(C)C</smiles><smiles>CCCC(C)C(C)C</smiles>

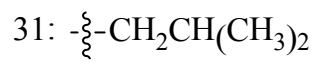

32: $\left\{-\mathrm{CH}_{2} \mathrm{CH}_{2} \mathrm{COOH}\right.$

33: $-\left\{-\mathrm{CH}_{2} \mathrm{COOH}\right.$

$34:$
35: $-\left\{-\mathrm{CH}_{2} \mathrm{OH}\right.$

25-35

Figure 13: The structure of series of 25-35.

S. aureus RN 4220 and S. aureus KCTC 503. To further improve the activities of these pyrazole-based $N$-carboxymethyl rhodanines, we also synthesized compounds $24 \mathrm{a}-\mathrm{O}$ via the addition of a benzyl moiety to the $\mathrm{N}$-carboxymethyl group (Figure 12) [62]. Among the synthesized compounds, compounds $24 \mathrm{a}-\mathrm{d}$ and $24 \mathrm{~m}$ showed high levels of activity towards S. aureus RN 4220 and S. aureus KCTC 503, with MIC values of $2 \mu \mathrm{g} / \mathrm{mL}$. Compounds 24b, 24d, 24g, 24h, 24j and $24 \mathrm{~m}$ showed significant levels of activity towards MRSA 3167 and MRSA 3506 with an MIC value of $1 \mu \mathrm{g} / \mathrm{mL}$.

Inspired by the high levels of efficiency achieved by these pyrazolebased $\mathrm{N}$-carboxymethyl rhodanines, we investigated the attachment of another pyrazole molecule to the $\mathrm{N}$-carboxymethyl rhodanine, as well as the introduction of a large number of substituents to the $\mathrm{N}$-carboxymethyl group, in terms of their influence on the antibacterial activity. In total, 11 series of compounds (25-35) were prepared and screened for their antibacterial activity (Figure 13) [63,64]. Compounds belonging to series 25-31, where hydrophobic groups had been introduced to the $N$-carboxymethyl moiety, exhibited high levels of inhibitory activity towards S. aureus RN 4220 and multidrugresistant Gram-positive strains (MRSA 3167 and MRSA 3506) with MIC values in the range of $2-8 \mu \mathrm{g} / \mathrm{mL}$. In contrast, compounds belonging to series $32-35$, where polar groups had been introduced to the $N$-carboxymethyl moiety, did not show any inhibitory activity at concentrations below $64 \mu \mathrm{g} / \mathrm{mL}$, which indicated that the introduction of polar groups to the $\mathrm{N}$-carboxymethyl moiety did not have a positive impact on the activity of the compounds.

\section{Conclusion}

In summary, several different series of $N$-carboxymethyl rhodanines have been synthesized and evaluated for their antibacterial activities. Compounds belonging to these series have been the subject of considerable interest from chemists and biologists, because of their high levels of activity against Gram-positive strains (including several multidrug-resistant clinical isolates). It is envisaged that further improvements will be made to the skeleton in the near future to obtain novel antibacterial agents.

\section{Acknowledgements}

This work was supported by the National Science Foundation of China (Grant no. 81260468). We would like to express our gratitude to the members for their contribution to $\mathrm{N}$-carboxymethyl rhodanines studies over the years.

\section{References}

1. Chopra I, Schofield C, Everett M, O'Neill A, Miller K, et al. (2008) Treatment of health-care-associated infections caused by Gram-negative bacteria: a consensus statement. Lancet Infect Dis 8: 133-139.

2. Overbye KM, Barrett JF (2005) Antibiotics: where did we go wrong? Drug Discov Today 10: 45-52.

3. Sangani CB, Mungra DC, Patel MP, Patel RG (2012) Synthesis and in vitro antimicrobial screening of new pyrano[43-b]pyrane derivatives of $1 \mathrm{H}$-pyrazole. Chin Chem Lett 23: 57-60.

4. Moellering RC Jr (2008) Current treatment options for community-acquired methicillin-resistant Staphylococcus aureus infection. Clin Infect Dis 46: 10321037.

5. Gualtieri M, Bastide L, Villain-Guillot $P$, Michaux-Charachon S, Latouche J, et al. (2006) In vitro activity of a new antibacterial rhodanine derivative against Staphylococcus epidermidis biofilms. J Antimicrob Chemother 58: 778-783.

6. Sim MM, Ng SB, Buss AD, Crasta SC, Goh KL, et al. (2002) Benzylidene rhodanines as novel inhibitors of UDP-N-acetylmuramate/L-alanine ligase. Bioorg Med Chem Lett 12: 697-699. 
7. Habib NS, Ridal SM, Badaweyl EAM, Fahmyl HTY, Ghozlan HA (1997) Synthesis and antimicrobial activity of rhodanine derivatives. Eur J Med Chem 32: 759-762.

8. Opperman TJ, Kwasny SM, Williams JD, Khan AR, Peet NP, et al. (2009) Aryl rhodanines specifically inhibit staphylococcal and enterococcal biofilm formation. Antimicrob Agents Chemother 53: 4357-4367.

9. Liu JC, Zheng CJ, Wang MX, Li YR, Ma LX, et al. (2014) Synthesis and evaluation of the antimicrobial activities of $3-((5-$ phenyl-1,3,4-oxadiazol-2-yl) methyl)-2-thioxothiazolidin-4-one derivatives. Eur J Med Chem 74: 405-410.

10. Petrikaite V, Tarasevicius E, Pavilonis A (2007) New ethacridine derivatives as the potential antifungal and antibacterial preparations. Medicina (Kaunas) 43: $657-663$

11. Inamori $Y$, Okamoto $Y$, Takegawa $Y$, Tsujibo H, Sakagami $Y$, et al. (1998) Insecticidal and antifungal activities of aminorhodanine derivatives. Biosci Biotechnol Biochem 62: 1025-1027.

12. Sortino M, Delgado P, JuÃ $r$ rez S, Quiroga J, AbonÃa R, et al. (2007) Synthesis and antifungal activity of (Z)-5-arylidenerhodanines. Bioorg Med Chem 15: 484494.

13. Siddiqui IR, Singh PK, Singh J, Singh J (2005) Facile synthesis and fungicidal activity of novel 4,4'-bis[2"-(5"'-substituted rhodanin-3"'-yl)thiazol-4"-yl] bibenzyls. Indian J Chem Sect B 44: 2102-2106

14. Schemmel KE, Padiyara RS, D'Souza JJ (2010) Aldose reductase inhibitors in the treatment of diabetic peripheral neuropathy: a review. J Diabetes Complications 24: 354-360.

15. Murugan R, Anbazhagan S, Lingeshwaran, Sriman Narayanan S (2009) Synthesis and in vivo antidiabetic activity of novel dispiropyrrolidines through $[3+2]$ cycloaddition reactions with thiazolidinedione and rhodanine derivatives. Eur J Med Chem 44: 3272-3279.

16. Heng S, Tieu W, Hautmann S, Kuan K, Pedersen DS, et al. (2011) New cholesterol esterase inhibitors based on rhodanine and thiazolidinedione scaffolds. Bioorg Med Chem 19: 7453-7463.

17. Cutshall NS, O'Day C, Prezhdo M (2005) Rhodanine derivatives as inhibitors of JSP-1. Bioorg Med Chem Lett 15: 3374-3379.

18. Irvine MW, Patrick GL, Kewney J, Hastings SF, MacKenzie SJ (2008) Rhodanine derivatives as novel inhibitors of PDE4. Bioorg Med Chem Lett 18 2032-2037.

19. Alegaon SG, Alagawadi KR, Sonkusare PV, Chaudhary SM, Dadwe DH, et al (2012) Novel imidazo[2,1-b][1,3,4]thiadiazole carrying rhodanine-3-acetic acid as potential antitubercular agents. Bioorg Med Chem Lett 22: 1917-1921.

20. Azizmohammadi M, Khoobi M, Ramazani A, Emami S, Zarrin A, et al. (2013) $2 \mathrm{H}$-chromene derivatives bearing thiazolidine-2,4-dione, rhodanine or hydantoin moieties as potential anticancer agents. Eur J Med Chem 59: 15-22.

21. Chandrappa S1, Kavitha CV, Shahabuddin MS, Vinaya K, Ananda Kumar CS, et al. (2009) Synthesis of 2-(5-((5-(4-chlorophenyl)furan-2-yl)methylene)4-oxo-2-thioxothiazolidin-3-yl)acetic acid derivatives and evaluation of their cytotoxicity and induction of apoptosis in human leukemia cells. Bioorg Med Chem 17: 2576-2584.

22. Rajamaki S, Innitzer A, Falciani C, Tintori C, Christ F, et al. (2009) Exploration of novel thiobarbituric acid-, rhodanine- and thiohydantoin-based HIV-1 integrase inhibitors. Bioorg Med Chem Lett 19: 3615-3618.

23. Ramkumar K, Yarovenko VN, Nikitina AS, Zavarzin IV, Krayushkin MM, et al. (2010) Design, synthesis and structure-activity studies of rhodanine derivatives as HIV-1 integrase inhibitors. Molecules 15: 3958-3992.

24. Kumar G, Parasuraman P, Sharma SK, Banerjee T, Karmodiya K, et al. (2007) Discovery of a rhodanine class of compounds as inhibitors of Plasmodium falciparum enoyl-acyl carrier protein reductase. J Med Chem 50: 2665-2675.

25. Ergenc N, Capan G, Gunay NS, Ozkirimli S, Güngor M, et al. (1999) Synthesis and hypnotic activity of new 4-thiazolidinone and 2-thioxo-4,5imidazolidinedione derivatives. Arch Pharm (Weinheim) 332: 343-347.

26. Rauter AP, Padilha M, Figueiredo JA, Ismael MI, Justino J, et al. (2005) Bioactive Pseudo-C-Nucleosides Containing Thiazole, Thiazolidinone, and Tetrazole Rings. J Carbohydr Chem 24: 275-296.

27. McGuire WC, O'Neill RC, Brody G (1966) Anthelmintic activity of 3-methyl-5[(p-nitrophenyl)azo]rhodanine. J Parasitol 52: 528-537.

28. Tomasic T, Masic LP (2009) Rhodanine as a privileged scaffold in drug discovery. Curr Med Chem 16: 1596-1629.
29. Bhatti RS, Shah S, Suresh, Krishan P, Sandhu JS (2013) Recent Pharmacological Developments on Rhodanines and 2,4-Thiazolidinediones. Int J Med Chem.

30. Xing C, Wang L, Tang X, Sham YY (2007) Development of selective inhibitors for anti-apoptotic Bcl-2 proteins from BHI-1. Bioorg Med Chem 15: 2167-2176.

31. Chauhan K, Sharma M, Saxena J, Singh SV, Trivedi P, et al. (2013) Synthesis and biological evaluation of a new class of 4-aminoquinoline-rhodanine hybrid as potent anti-infective agents. Eur J Med Chem 62: 693-704.

32. Nitsche C, Klein CD (2012) Aqueous microwave-assisted one-pot synthesis of $\mathrm{N}$-substituted rhodanines. Tetrahedron Lett 53: 5197-5201

33. Alizadeh A, Rostamnia S, Zohreh N, Hosseinpour R (2009) A simple and effective approach to the synthesis of rhodanine derivatives via threecomponent reactions in water. Tetrahedron Lett 50: 1533-1535.

34. Azizi N, Aryanasab F, Torkiyan L, Ziyaei A, Saidi MR (2006) One-pot synthesis of dithiocarbamates accelerated in water. J Org Chem 71: 3634-3635.

35. Singh SJ, Chauhan SMS (2013) Potassium carbonate catalyzed one pot fourcomponent synthesis of rhodanine derivatives. Tetrahedron Lett 54: 24842488.

36. Tomasic T1, Peterlin Masic L (2012) Rhodanine as a scaffold in drug discovery: a critical review of its biological activities and mechanisms of target modulation. Expert Opin Drug Discov 7: 549-560.

37. Pardasani RT, Pardasani P, Sherry D, Chaturvedi V (2001) Synthetic and antibacterial studies of rhodanine derivatives with indol-2,3-diones. Indian Chem Sect B 40: 1275-1278.

38. Grant EB1, Guiadeen D, Baum EZ, Foleno BD, Jin H, et al. (2000) The synthesis and SAR of rhodanines as novel class $C$ beta-lactamase inhibitors. Bioorg Med Chem Lett 10: 2179-2182.

39. Gandhe S, Gautam MD (2004) Synthesis and microbial activity of 5-(2-methyl4-N-cyanoethyl-N-benzenesulphonyl aminobenzylidene)rhodanine and its metal complexes. Asian J Chem 16: 261-264.

40. Hardej D, Ashby CRJ, Khadtare NS, Kulkarni SS, Singh S, et al. (2010) The synthesis of phenylalanine-derived C5-substituted rhodanines and their activity against selected methicillin-resistant Staphylococcus aureus (MRSA) strains. Eur J Med Chem 45: 5827-5832.

41. Patel BA, Ashby CR Jr, Hardej D, Talele TT (2013) The synthesis and SAR study of phenylalanine-derived (Z)-5-arylmethylidene rhodanines as antimethicillin-resistant Staphylococcus aureus (MRSA) compounds. Bioorg Med Chem Lett 23: 5523-5527.

42. Tomasic T, Zidar N, Kovac A, Turk S, Simcic M, et al. (2010) 5-Benzylidenethiazolidin-4-ones as multitarget inhibitors of bacterial Mur ligases. ChemMedChem 5: 286-295.

43. Tomasic T, Zidar N, Mueller-Premru M, Kikelj D, Masic LP (2010) Synthesis and antibacterial activity of 5-ylidenethiazolidin-4-ones and 5-benzylidene-4,6pyrimidinediones. Eur J Med Chem 45: 1667-1672.

44. Alegaon SG, Alagawadi KR (2011) Synthesis, characterization and antimicrobia activity evaluation of new imidazo[2,1-b][1,3,4]thiadiazole derivatives. Eur $\mathrm{J}$ Chem 2: 94-99.

45. Chen ZH, Zheng CJ, Sun LP, Piao HR (2010) Synthesis of new chalcone derivatives containing a rhodanine-3-acetic acid moiety with potential antibacterial activity. Eur J Med Chem 45: 5739-5743.

46. Jin X, Zheng CJ, Song MX, Wu Y, Sun LP, et al. (2012) Synthesis and antimicrobial evaluation of $L$-phenylalanine-derived $C 5$-substituted rhodanine and chalcone derivatives containing thiobarbituric acid or 2-thioxo-4thiazolidinone. Eur J Med Chem 56: 203-209.

47. Song MX, Deng XQ, Li YR, Zheng CJ, Hong L, et al. (2013) Synthesis and biological evaluation of (E)-1-(substituted)-3-phenylprop-2-en-1-ones bearing rhodanines as potent anti-microbial agents. J Enzyme Inhib Med Chem.

48. Xing XL, Liu TT, Song MX, Li YR, Zhang Y, et al. (2013) Synthesis and biological evaluation of $\mathrm{N}$-substituted rhodanine derivatives bearing chalcone moiety as potent antimicrobial agents. Chin J Med Chem 23: 1-7.

49. Song MX, Zheng CJ, Deng XQ, Wang Q, Hou SP, et al. (2012) Synthesis and bioactivity evaluation of rhodanine derivatives as potential anti-bacterial agents. Eur J Med Chem 54: 403-412.

50. Miao J, Zheng CJ, Sun LP, Song MX, Xu LL, et al. (2013) Synthesis and potential antibacterial activity of new rhodanine-3-acetic acid derivatives. Med Chem Res 22: 4125-4132. 
Citation: Song MX, Zheng CJ, Deng XQ, Wei ZY, Piao HR (2014) The Synthesis and Anti-Bacterial Activities of N-carboxymethyl Rhodanines. Med chem 4: 441-448. doi:10.4172/2161-0444.1000177

51. Guo M, Zheng CJ, Song MX, Wu Y, Sun LP, et al. (2013) Synthesis and biological evaluation of rhodanine derivatives bearing a quinoline moiety as potent antimicrobial agents. Bioorg Med Chem Lett 23: 4358-4361.

52. Li W, Zheng CJ, Sun LP, Song MX, Wu Y, et al. (2013) Novel arylhydrazone derivatives bearing a rhodanine moiety: synthesis and evaluation of their antibacterial activities. Arch Pharm Res.

53. Che J, Zheng CJ, Song MX, Bi YJ, Liu Y, et al. (2014) Synthesis and antibacterial evaluation of furan derivatives bearing a rhodanine moiety. Med Chem Res 23: 426-435.

54. Patel MV, Bell R, Majest S, Henry R, Kolasa T (2004) Synthesis of 4,5-diaryl$1 \mathrm{H}$-pyrazole-3-ol derivatives as potential COX-2 inhibitors. J Org Chem 69: 7058-7065.

55. Girisha KS, Kalluraya B, Narayana V, Padmashree (2010) Synthesis and pharmacological study of 1-acetyl/propyl-3-aryl-5-(5-chloro-3-methyl-1-phenyl1H-pyrazol-4-yl)-2-pyrazoline. Eur J Med Chem 45: 4640-4644.

56. Sullivan TJ, Truglio JJ, Boyne ME, Novichenok P, Zhang X, et al. (2006) High affinity InhA inhibitors with activity against drug-resistant strains of Mycobacterium tuberculosis. ACS Chem Biol 1: 43-53.

57. Liu XH, Cui P, Song BA, Bhadury PS, Zhu HL, et al. (2008) Synthesis, structure and antibacterial activity of novel 1-(5-substituted-3-substituted-4,5dihydropyrazol-1-yl)ethanone oxime ester derivatives. Bioorg Med Chem 16: 4075-4082.

58. Gilbert AM, Failli A, Shumsky J, Yang Y, Severin A, et al. (2006) Pyrazolidine- 3,5-diones and 5-hydroxy-1H-pyrazol-3(2H)-ones, inhibitors of UDP-Nacetylenolpyruvyl glucosamine reductase. J Med Chem 49: 6027-6036.

59. Prakash O, Kumar R, Parkash V (2008) Synthesis and antifungal activity of some new 3-hydroxy-2-(1-phenyl-3-aryl-4-pyrazolyl) chromones. Eur J Med Chem 43: 435-440.

60. Sharma PK, Kumar S, Kumar P, Kaushik P, Kaushik D, et al. (2010) Synthesis and biological evaluation of some pyrazolylpyrazolines as anti-inflammatoryantimicrobial agents. Eur J Med Chem 45: 2650-2655.

61. Xu LL, Zheng CJ, Sun LP, Miao J, Piao HR (2012) Synthesis of novel 1,3-diaryl pyrazole derivatives bearing rhodanine-3-fatty acid moieties as potential antibacterial agents. Eur J Med Chem 48: 174-178.

62. Zheng CJ, Xu LL, Sun LP, Miao J, Piao HR (2012) Synthesis and antibacterial activity of novel 1,3-diphenyl-1H-pyrazoles functionalized with phenylalaninederived rhodanines. Eur J Med Chem 58: 112-116.

63. Zheng CJ, Song MX, Sun LP, Wu Y, Hong L, et al. (2012) Synthesis and biological evaluation of 5-aryloxypyrazole derivatives bearing a rhodanine3-aromatic acid as potential antimicrobial agents. Bioorg Med Chem Lett 22 7024-7028.

64. Song MX, Zheng CJ, Deng XQ, Sun LP, Wu Y, et al. (2013) Synthesis and antibacterial evaluation of rhodanine-based 5-aryloxy pyrazoles against selected methicillin resistant and quinoloneresistant Staphylococcus aureus (MRSA and QRSA). Eur J Med Chem 60: 376-385. 